Meta

Journal des traducteurs

Translators' Journal

\title{
Translation of Binominal Phrases
}

\section{Irène V. Spilka}

Volume 22, numéro 3, septembre 1977

URI : https://id.erudit.org/iderudit/004247ar

DOI : https://doi.org/10.7202/004247ar

Aller au sommaire du numéro

Éditeur(s)

Les Presses de l'Université de Montréal

ISSN

0026-0452 (imprimé)

1492-1421 (numérique)

Découvrir la revue

Citer cet article

Spilka, I. V. (1977). Translation of Binominal Phrases. Meta, 22(3), 171-183.

https://doi.org/10.7202/004247ar d'utilisation que vous pouvez consulter en ligne.

https://apropos.erudit.org/fr/usagers/politique-dutilisation/ 


\section{Translation of Binominal Phrases*}

Words and expressions recently coined in the scurce-language, and for which the target-language has no ready-made equivalents are a constant source of difficulty for translators. The problem is compounded when the target-language forces the writer to make a kind of discrimination that is nonexistent, or at least not essential, in the source-language.

When I recently asked a group of students how they would translate the title of an article which had appeared in The New York Times as "The Poor and the Work Ethic $>$, they hesitated over work ethic, fell back on the well learned pattern supplied by le Code du travail, and suggested «Les pauvres et l'éthique du travail $\gg$. They were then asked to justify this answer, and a general discussion ensued. When it was brought to their attention that pleasure principle, in Freud's writings, is translated by a reputable dictionary of psychoanalysis, as principe de plaisir, they were at a loss to account for the presence of a definite article in one case and its absence in the other. Several experienced translators, when faced with the same question, stated flatly that they always deferred to l'usage since they were native speakers of French. When usage failed them, they simply trusted their intuition.

Now, intuition probably serves the native speaker well enough, but a translator is in constant contact with a foreign language, and as a result he may find that his flair for native words has, in time, become somewhat dulled. On the other hand, it is the task of a theory of translation to account for correct or felicitous intuitions on the part of practitioners of translation. What is suggested in this paper is that rules can be found to account for certain regular equivalences between speech acts occurring in different languages. Without raising the broader issue of the form a definitive theory of translation should take, it is safe to say that some progress can be made, at this time, by exploring the research instruments that will contribute to shaping a method of study. Contrastive linguistics may provide the best instrument available at present.

To be sure, contemporary linguistics appears to be suffering from an embarassment of riches where theories of language are concerned, and it may

* Paper presented at the BAAL Seminar on Translation, held at the University of Exeter, September 13-14, 1976. 
be difficult to select the particular grammar that would best be suited to the purposes of translation theory - or translatology, as some prefer to call it. Linguistic methods, however, are fairly well standardized and comparatively easy to apply for anyone with some training in language, mathematics or philosophy, or simply endowed with the power of logical thinking.

Comparison, substitution, and deletion are some of the more basic operations performed by linguists in order to uncover the rules governing ordinary speech. Since translation is a form of speech, reported speech as it were - the role of the translator being, in essence, to tell the reader : \&I have read this text, and I declare that its author says as follows : ... same kind of analysis as original speech. Let us then examine the problem at hand, the translation of expressions similar to (the) work ethic.

We might call them binominal phrases since they contain two nouns. This will serve to indicate that noun phrases composed of a noun and an adjective or other part of speech are not included in this study. It should also be noted that not all French binominal phrases have binominal English equivalents. Single English words, such as potato and (Petroleum industries) swivel must often be translated by means of a phrase : pomme de terre, tête d'injection. The converse is equally true. The English phrase (Railways) centre rail has a single word equivalent in French, namely crémaillere. Finally, back translation reveals that some French binominal phrases, just as some single nouns do, have more that one meaning in English. Thus femme de chambre has three English equivalents : chambermaid, housemaid and lady's maid. None of this, however, is relevant to the problem at hand, which has to do with inserting a determiner after the preposition within the phrase.

On the basis of form alone, French binominal phrases can be classified into three groups, as follows :

$$
\begin{aligned}
& \text { A - Juxtaposed : cheval(-)vapeur ', (horse power); } \\
& \text { B - Linked without determiner : tête de pont, (bridgehead); } \\
& \text { C - Linked and with determiner : garde du corps (body-guard). }
\end{aligned}
$$

A second classification can be devised on the basis of syntax. Some phrases cannot be abbreviated without changing their meaning entirely. Others can and are often abbreviated, but may not have a determiner inserted before their second noun. In the third group, a definite or indefinite determiner alternates with zero determiner. Thus we have three more classes :

$\mathrm{D}-$ Robe de chambre, (dressing gown) vs. robe, (dress);

$\mathrm{E}-$ Vaisseau (de guerre), (warship / man-of-war);

$$
\text { F- Peau }\left\{\begin{array}{l}
\text { d'orange } \\
\text { d'une orange } \\
\text { de l'orange }
\end{array}\right\} \text { (orange peel). }
$$

1. The presence of the hyphen depends on the dictionary consulted. 
Class $\mathrm{E}$ noun phrases sometimes appear to behave like class $\mathrm{F}$ noun phrases, but this is the result of ellipsis, which serves to avoid: redundancy in the surface structure of an utterance. Consider, by way of illustration, the following sets of possible utterances :

1. a) Un garçon de café s'approche de notre table.

b) Le garçon de café s'approche de notre table.

c) Un garçon du café d'en face s'approche de notre table.

d) Le garçon du café d'en face s'approche de notre table.

e) Un garçon d'un café des environs s'approche de notre table.

f) Le garçon d'un café des environs s'approche de notre table.

g) Garçon!

$1^{\prime}$ a) A waiter is coming towards our table.

b) The waiter is coming towards our table.

c) A waiter from the cafe across the street...

d) The waiter from the cafe across the street...

e) A waiter from a neighbouring cafe...

f) The waiter from a neighbouring cafe...

g) Waiter!

In $1, a$ and $b$, waiter is translated by the full phrase garçon $\ddot{d e}$ café, while in $1, c$ to $g$, it is abbreviated to garçon. By recovering the deleted words in 1 , $c$ to $f$, one can easily see that $d u$ and $d$ 'un are the determiners of café d'en face and café des environs respectively :

1" un/le garçon de café du café d'en face / d'un café des environs Class $F$ phrases, on the other hand, do not behave in the same manner. The examples contained in 2 are ungrammatical :

2. * une / la peau d'orange d'une / de l'orange de Jaffa

* un / le portrait de femme d'une / de la femme que j'aime

* des / les statues de pierre d'une / de la pierre appelée cornaline

Clearly, it is this class of noun phrases (F) which is likely to cause problems in translation.

In order to give this study a basis in empirical facts, and to secure « real 》 quotations rather than examples «manufactured 》 by a linguist, as well as to get a general idea of the relative frequency of binominal phrases in current prose, data was obtained from a short prose passage (approximately 3000 ) words published simultaneously in English and French ${ }^{2}$. By comparing each binominal phrase with its counterpart in the opposite language, a total of sixteen pairs of examples were collected, and arranged into five sets, as follows :

1) Expressions of quantity 2

2) Genetive form 2

2. The Royal Bank of Canada Monthly Letter and La Banque Royale du Canada, Bulletin Mensuel, 57.7 (juillet 1976). 
$\begin{array}{ll}\text { 3) Nominalization } & 2 \\ \text { 4) Characterization } & 4 \\ \text { 5) Strict specification } & 6 \text { * }\end{array}$

Since statistical description is not essential to structural description, no attempt was made to secure additional data, or to calculate average frequency for each type.

\section{Expressions of quantity}

Investigating expressions of quantity proved to be a good starting point. The two members of this set in our sample are given below:
3. a) a little money
$\rightleftarrows$
3. a) un peu d'argent
b) a dozen banks $\rightleftarrows$
b) une douzaine de banques

In both instances, the noun phrase is preceded by an indefinite determiner. Since theoretically a noun phrase may occur with zero determiner or with a definite determiner, it is reasonable to ask whether the presence and the nature of the noun phrase determiner (NP det) affects the structure of the phrase itself, that is whether the determiner of the second noun varies according to the NP det.

Theoretical possibilities can be summarized thus :

4. $\left[\begin{array}{l}\varnothing \\ a \\ \text { the }\end{array}\right] \mathrm{NQ}\left[\begin{array}{l}\varnothing \\ a \\ \text { the }\end{array}\right] \mathrm{N} \rightleftarrows\left[\begin{array}{l}\varnothing \\ u n(e) \\ \text { des } \\ l e / l a \\ \text { les }\end{array}\right] \mathrm{NQ}$ de $\left[\begin{array}{l}\varnothing \\ u n(e) \\ \text { des } \\ \text { le/la } \\ \text { les }\end{array}\right] \mathrm{N}$

Furthermore the NP may be a subject or an object. Let us consider only the most interesting cases.

5. a) Jane has little money to spend on clothes.

b) A little rain would do no harm.

c) The little care this mother takes of her child is shocking.

$5^{\prime}$ a) Jeanne a peu d'argent à consacrer à sa toilette.

b) Un peu de pluie ne ferait pas de mal.

c) Le peu de soin que cette mère prend de son enfant est honteux.

From these it can be seen that the NP DET may vary $(\varnothing, a$, the / $\varnothing, u n, l e)$ without affecting the determiner of the second noun. A definite DET, however, is possible only in the presence of a restrictive relative clause. These observations are equally valid with other quantifiers than the ones shown above, although certain constraints must be taken into account : enough / a sufficient quantity of much / a (the) large quantity of. We shall also see, further on, that countable nouns do not behave exactly as mass nouns.

* Not discussed in this paper since then do not belong to class G. See Appendix for list. 
Our next question concerns the breakdown of $\mathrm{N}^{\mathrm{Q}}$ de $\mathrm{N}$. In order to find out whether de belongs with the expression of quantity or with the noun following it, we may test by means of two operations, deletion (6. $a$ and $b$ ) and substitution (7. $a, b$ and $c$ ).

6. a) Peu me suffit.

b) J'exige peu.

7. a) *Peu m'en suffit.

b) * Son peu me suffit.

c) J'en veux peu.

Ellipsis or deletion of the modifier is possible but not always acceptable (* Je veux peu.) in the case of an NP in subject position. Pronominalization of the second noun is not possible in subject position. Where pronominalization is possible, the pronoun $e n$ is the only proper substitute. We know that en replaces an NP preceded by de: se moquer du sort / d'un infirme / des autres $\rightarrow$ s'en moquer. This would indicate that de belongs with the following noun, and not with the quantifier, a fact clearly illustrated in 8 and 9 :

8. a) Peu (de temps) après l'arrivée de Paul...

b) Un peu (de vin) pour Pierre, s'il vous plait.

c) C'est l'excédent (de bagages) qui coûte cher.

9. a) Il en faudra beaucoup (de bière).

b) Nous en avons trop au Canada (de neige).

c) Georges en prend juste assez pour déranger Luc (de place).

Further confirmation that de belongs with the following noun, and not with the preceding quantifier, is provided by ellipsis of the latter after a coordinating conjunction, as in 10 :

10. a) Un peu de temps et d'argent me permettrait de réussir.

b) Donnez-nous beaucoup de pain et de fromage.

c) Le peu de temps et de soin que vous consacrez à la préparation de vos cours explique votre échec.

Examples 6 to 10 have served the purpose of showing how the French $\mathrm{N}^{0}$ de $\mathrm{N}$ phrase corresponding to the English $\mathrm{N}^{\mathrm{Q}} \mathrm{N}$ phrase can be segmented, and we might wish to write it as $\mathrm{N}^{\mathrm{Q}}+d e \mathrm{~N}$.

We must now find out which part of the sequence constitutes the head of the phrase. As we shall see, the decision cannot be made on the basis of syntax alone. Consider

11. a) *Peu / assez / beaucoup de lecteurs a répondu.

b) Peu / assez / beaucoup de lecteurs ont répondu.

c) Un peu de vin et de bière n'a jamais fait de mal à personne. 
d) Un peu de vin et de bière n'ont jamais fait de mal à personne.

e) Le peu de soins qu'elle a reçus lui a coûté la vie.

f) Le peu de soins qu'elle a reçus lui ont sauvé la vie.

The only difference between $a, c, e$ and $b, d, f$ is to be found in subject verb agreement. While $a$ is ungrammatical, $b$ and $c$ are equally acceptable to many speakers of French, and $e$ and $f$ have different meanings : $e$ expresses the fact that the amount of care the patient received was insufficient to maintain life, but $f$ states that however small, this amount was suficicient. The information necessary to sort out the head from the modifier in the noun phrase is supplied by the verb in the verb phrase, and is of a semantic nature : readers, that is human beings, can answer questions, but a quantity cannot; wine and beer, inanimate objects, and the quantity there of can hurt someone or something; medical attention is what saves patient, but the lack or insufficient quantity of it is what causes him to die. This possibility of shifting emphasis from one noun to the other within the noun phrase no doubt contributes to the ambiguity of certain binominal expressions.

So far we have looked only at quantifiers in connection with mass nouns. However an examination of expressions of quantity must also include a review of quantifiers together with count nouns. Again we will consider only relevent cases.

12. a) Twelve men came to see the foreman.

b) A dozen men came to see the foreman.

c) The dozen men who work in Jack's department were fired.

13. a) $A$ dozen men form a jury.

b) A dozen eggs now costs 994 in Montreal.

c) Eggs now cost $99 \phi$ a dozen in Montreal.

$12^{\prime}$ a) Douze hommes sont venus voir le contremaître.

b) Une douzaine d'hommes sont venus voir le contremaitre.

c) La douzaine d'hommes qui travaillent chez Jacques ont été licenciés.

$13^{\prime}$ a) Douze hommes forment un jury.

b) Une douzaine d'aufs coûte maintenant $99 \not \dot{a}$ à Montréal.

c) Les oufs coûtent maintenant $99 \not \dot{\phi}$ à Montréal.

In 12. and $12^{\prime} a$, we see that numerals can occur without a determiner. Examples $b$ shows dozen preceded by an indefinite determiner. Examples $c$ illustrate the fact that a definite determiner can occur only when the following expression of quantity is modified by a restrictive relative clause. In 13 . and $13^{\prime} a$, the verb agrees with the noun following the quantifier, while in $b$ it agrees with the quantifier itself. Examples 13. $c$ and $13^{\prime} c$ show a difference between English and French use of the article preceding dozen/douzaine. Whereas English retains the indefinite determiner with the quantifier in postposition, French allows only a «definite article in postposition while it permits either 
a definite or an indefinite determiner in anteposition : $13^{\prime} b$ and $c$ are interchangeable. This raises the question of how definite the so-called definite article is in French, and this question is not unimportant, since French has many noun numerals : une dizaine, une vingtaine, ... une centaine, un millier, un milliard, un million, ... as opposed to a dozen, a hundred, a thousand, a million, etc., in English, with tens occurring only in tens of thousands. English, however, can contrast definiteness and indefiniteness in other ways.

14. a) Twelve men were told to stay. / =INDEF/

b) Twelve / a dozen of the men were told to stay, and five (of them) were told to leave. $/=\mathrm{DEF} /$

$14^{\prime}$ a) Douze hommes ont été autorisés à rester. /=INDEF/

b) * douze / une douzaine des hommes ont été autorisés à rester, et cinq (d'entre eux) ont été autorisés à s'en aller.

c) Douze / une douzaine des hommes qui étaient là ont été autorisés à rester, et cinq (d'entre eux) ont été autorisés à s'en aller. $/=\mathrm{DEF} /$

Example $14^{\prime} b$ is ungrammatical because the contracted form des can stand for $d e+l e s$ as well as for $d e+d e s$, neither of which can occur in surface structure. In order to translate $14 . b$ adequately, a restrictive relative clause must be introduced. This is not the case in English, where of the supplies the necessary degree of definiteness. We can thus set down the following equivalences :

15. a) Twelve men $A$ dozen men

$$
\begin{aligned}
& \begin{array}{l}
\text { Douze hommes } \\
\text { Une douzaine d'hommes }
\end{array} \\
& \text { b) Twelve of the men = Douze des hommes qui.. } \\
& \text { Une douzaine des hommes qui... } \\
& \text { / = RESTRICT./ }
\end{aligned}
$$$$
A \text { dozen of the men }=\text { /=RESTRICT. CL./ }
$$

Returning for a moment to mass nouns, we will recall that peu, etc. can be contrasted with $u n$ peu and le peu + RELATIVE to indicate three degrees of definiteness, namely zero, indefinite, definite. The absence of an article before numerals might, at first, lead us to believe that zero article has the same value before mass nouns as before count nouns. Consider, however, the meaning of twelve in 16 :

16. a) Twelve men can form a jury.

b) Twelve men (,who opposed the motion,) abstained from voting.

c) The twelve men who opposed the motion abstained from voting.

In example 16. a, twelve men refers to any men; in $b$, twelve men refers to a definite set of men who remain however, unspecified; and in $c$, the twelve men refers to $a$, specified set of men. We must then conclude that zero determiner before a numeral is ambiguous (specific or unspecific) and is not identical with zero determiner before a nominal quantifier. These findings can be summarized in a table contrasting definiteness with specification or determination. 
TABLE I

\begin{tabular}{|c|c|c|c|c|}
\hline & \multicolumn{2}{|c|}{ Degree : } & \multirow{2}{*}{$\begin{array}{l}\text { QUANTIFIER } \\
\text { DETERMINER }\end{array}$} & \multirow{2}{*}{$\begin{array}{c}\text { NOUN } \\
\text { DETERMINER }\end{array}$} \\
\hline & & & & \\
\hline 1. & - & - & $\varnothing$ & $\varnothing$ \\
\hline 2. & + & - & $a / / u n / l e^{x}$ & $\varnothing$ \\
\hline 3. & + & + & the $/ / l e^{1}$ & the // les \\
\hline
\end{tabular}

1. Gender is irrelevant.

Line 2 accounts for example $b$ and $c$ in 13 and $13^{\prime}$ above (given certain constraints on position). It also indicates two values of the French «definite » article.

The import of this brief exercise concerning the expression of quantity is threefold. First, we have seen that in a particular instance of the French phrase structure $\mathrm{X}_{1} \mathrm{~N}_{1}$ de $\mathrm{X}_{2} \mathrm{~N}_{2}$ where $\mathrm{X}_{1} \mathrm{~N}_{1}$ is a quantifier, de $\mathrm{X}_{2} \mathrm{~N}_{2}$ forms a detachable constituent, that can either be deleted or replaced by a pronoun. Secondly, we have found that the head of the phrase may be either the quantifier or the following noun. In each case, deletion and pronoun substitution are subject to specific constraints. Finally, we were able to establish a scale of definiteness and determination governing the occurrence of determiners. These three observations will provide us with the necessary tools to effect adequate translation of other classes of binominal phrases.

Genitive form

The set of genitive forms in our sample comprises two examples :

17. a) the branch manager

(of a bank in a rural village)

17. b) magazine article $17^{\prime}$ a) le directeur de la succursale (d'une banque dans un petit village)

$17^{\prime}$ b) article de revue

What is striking here is that English does not require a determiner before $\mathrm{N}_{2}$ regardless of the degree of definiteness and determination, and that since the modifier, in this case, is anteposed, a single NP DET serves for both the head and the modifier :

18. a) $A$ branch manager is only an employee.

b) The branch manager has several functions to perform.

c) The branch manager of a bank in a small town was called Jones.

$18^{\prime}$ a) Un directeur de succursale n'est qu'un employé.

b) Le directeur de succursale remplit plusieurs fonctions.

c) Le directeur de la succursale d'une banque située dans une petite ville s'appelait Jones. 
On the other hand, English permits the occurrence of two indefinite determiners :

19. A manager of a branch knows what is best for his branch. while French does not:

$19^{\prime}$ a) *Un directeur d'une succursale sait ce qui convient à sa succursale.

b) Le directeur d'une succursale sait ce qui convient à sa succursale.

c) Un directeur de succursale sait ce qui convient à sa succursale.

In fact, le $\mathrm{N} d^{\prime} u n N$ is equivalent to $u n \mathrm{~N}$ de $\mathrm{N}$ and the two forms are interchangeable ${ }^{3}$.

The handling of English NN structures illustrated in 17 requires breaking down the phrase into its constituents and restoring the head - modifier word order, which yields the following possibilities :

(MODIFIER)

an $\mathrm{N}$ of (any) $\mathrm{N}$

the $\mathrm{N}$ of (any) $\mathrm{N}$

indefinite /characterization/

an $\mathrm{N}$ of $a$ (given) $\mathrm{N}$

the $\mathrm{N}$ of $a$ (given) $\mathrm{N}$

definite unspecified

an $\mathrm{N}$ of the $\mathrm{N}$

the $\mathrm{N}$ of the $\mathrm{N}$

definite specified /=UNDETERMINED/

The scale of definiteness-determination can then be applied as follows :

TABLE II

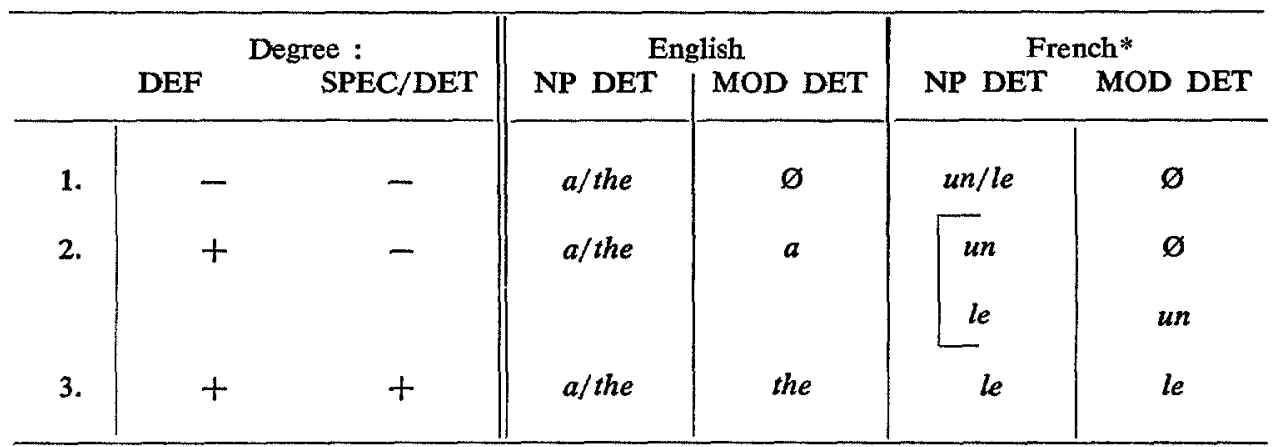

* Gender and contraction rules apply but are not relevant to degree.

Line 1 shows a type of «genitive» which one might be tempted to label characterization, since no particular \&possessor» can be identified in the situation. Granied that there can be no branch managers without branches to manage,

3. See Colette Coursaget-Colmerauer, * Etude des Structures du type nom de nom *. Unpublished Ph.D. dissertation, University of Montreal, 1975. 
it is not unreasonable to imagine that objects could be made for things or people that do not, or no longer, exist. Compare 20. $a$ with $b$ and $c$ :

20. a) Il fabrique des vêtements d'enfants, mais il n'y a pas d'enfants dans notre île.

b) Le manteau d'un enfant / un manteau d'enfant traîne sur un banc.

c) Le manteau de l'enfant était couvert de neige.

In $b$ ellipsis is possible : le manteau / un manteau traîne sur un banc. In $c$ pronominalization is possible : son manteau était couvert de neige. In $a$, however, neither ellipsis nor pronominalization can be applied. There is nevertheless a difference between characterization and the "genitive». Bank employee, horse hair, radio antenna and similar expressions may be paraphrased as an employee of the bank, the hair of a horse, the antenna of the radio. (In many cases, the genitive form's is present, as in children's clothing, Gemology, cat's eye, the water's edge, but this presents no special difficulty for the translator.) These phrases may also be glossed by means of a sentence containing to have (with the meaning of to possess) : the bank has an employee, a horse has hair, the radio has the antenna. In the case of characterization, similar paraphrases and glosses are not possible : baby blue, *a baby has blue, * the blue of a baby; fire hydrant, * a hydrant of the fire, * the fire has a hydrant.

\section{Nominalization}

Nominalization is perhaps more frequent in French than in English, where a gerund is often preferred to a noun. Example 20, for instance, could just as easily expressed by manipulating thought.

\section{Thought manipulation \\ 21. Machinery order \\ $20^{\prime}$ Le remaniement des idées \\ 21' Commande de machines}

Several features characterize this class of phrases in English : 1) frequency of. certain noun endings (in the head noun), such as -ation, -ment, -ity, etc.; 2) existence of a corresponding verbal : manipulation $<$ to manipulate, improvement $<$ to improve, dependability dependable $<$ to depend; 3) possibility of constructing the sentence with a gerund : the recall of things past / recalling things past; the impressment of seamen / impressing seamen. In French, nominalization is also characterized by certain noun endings : -ation, -ment, -ité, etc., and by corresponding verbal forms : rédaction $<$ rédiger, recrutement $<$ recruter, coupe < couper.

Determiners of such phrases are, once again, a function of definiteness and determination. Care must be taken to distinguish between these features in the head noun and in the modifier which is derived from the object NP of the verb that has been nominalized. One must also bear in mind that in English, the determiner does not occur before an abstract noun, whilst in French, the generic «definite » article is required : life is difficult / la vie est difficile, Mary loves cleanliness / Marie aime la propreté. Nine combinations 
of determiners are therefore possible in English, and five in French, since le can be both generic and specific, and since un...de-un... does not occur.

\begin{tabular}{l}
$\frac{\begin{array}{l}\text { TABLE III } \\
\text { (conflated) }\end{array}}{(a / \text { the }) \mathrm{N}+\text { of }(a / \text { the }) \mathrm{N}}\left[\begin{array}{l}\text { le/la/les } \\
\text { un }\end{array}\right] \mathrm{N}+\operatorname{de}\left[\begin{array}{l}\text { un/le/la/les } \\
\varnothing\end{array}\right] \mathrm{N}$ \\
\hline
\end{tabular}

In the text under consideration, thought manipulation occurred as a noun complement: (...in this age) of thought manipulation, and was translated as (...à notre époque) de remaniement des idées, since the phrase itself required zero determiner according to its function in the sentence. The other example, a large machinery order was an object NP preceded by an indefinite article, which was translated as (...qui voulait obtenir) une importante commande de machines. It is interesting to note in passing, that in both examples the English modifier noun being used as an epiteth does not have a plural marker, while in French it is necessary to discriminate between singular and plural objects.

Other examples of nominalization were numerous in our French corpus, although they did not happen to translate English $\mathrm{XN}+\mathrm{YN}$ phrases, and consequently were not retained in our sample. These can serve to illustrate further the patterns presented in Table III :

22. (.../des/ faiblesses causées par) le manque d'expérience...

23. La rédaction d'une annonce (n'est pas une chose à prendre à la légère...)

24. (...insister sur) lamélioration de la publicité...

And many more examples could be found elsewhere :

25. (Il faudra procéder à) une redistribution des tâches.

26. Les remaniements successifs des textes soumis par Pierre lont exigé beaucoup de temps.)

\section{Characterization}

Characterization may be effected in a variety of ways since a noun can be modified by adjectives, nouns, noun phrases, and relative clauses.

The following four cases of characterization by means of a noun or noun phrase were found in the corpus :

27. a) shoe store

b) shoe shine stand operator

c) sales methods

d) sales plan 
$27^{\prime}$ a) magasin de chaussures

b) cireur de bottes

c) méthode de vente

d) campagne de vente

You will recall that, under genitive, we looked at some of the features which set these two classes apart, and we saw that paraphrasing with $\mathrm{N}$ of $\mathrm{N}$, or glossing with a sentence containing to have (meaning to possess) were not possible. Further tests can differentiate these two classes of phrases.

Deletion of the head noun after a coordinating conjunction is possible in the case of the genetive :

28. a magazine and a newspaper article both reported the discovery of $X Y Z$ by $N$...

28' un article de la revue et du journal ont fait état de la découverte de $X Y Z$ par $N$...

but not in the case of characterization :

29. * a shoe and hat store are opening on Bond Street next week.

$29^{\prime} *$ un magasin de chaussures et de chapeaux vont ouvrir leur porte la semaine prochaine.

Substitution of a possessive for the modifier, when the latter is not an animate, is sometimes feasible, although with difficulty in certain cases (while deletion seems more « natural ».)

30. a) The garage roof caved in.

b) Its roof caved in.

c) The roof caved in.

$30^{\prime}$ a) Le toit du garage s'est effondré.

b) Son toit s'est effondré.

c) Le toit s'est effondré.

It's never possible in the case of characterization :

31. a) a shoe store

b) * its / their store

c) the sales plan

d) * their plan $31^{\prime}$ a) un magasin de chaussures

b) * leur magasin

c) la campagne de vente

d) * sa campagne

Characterization phrases, unlike expressions of quantity, genitive, and nominalization phrases, do not admit of a three way contrast of definition and determination, the modifier always being an epiteth always requires zero determiner.

Back to the work ethic

We are now in a position to translate (the) work ethic, and what is more, to justify our translation : l'éthique de travail. To be sure, the French sequence 
l'éthique du travail is entirely grammatical and meaningful but, and this is the important point, it means something different.

L'éthique de travail refers to an ethic, inherited from the Protestant Reformation, which stresses the importance of work, its inherent goodness and the respectability which it confers on those who perform it. L'éthique $d u$ travail, on the other hand, refers to the code of ethics which a particular work, or more accurately, a particular body of workers have evolved. Thus we may speak of professional ethics in connection with translation, as l'éthique de la profession. This, by the way, is also known as déontologie, a term that could never be synonymous with l'éthique de travail.

\section{Summary and conclusion}

We have examined four classes of phrases : 1. expressions of quantity, 2. genitives, 3. nominalization and 4. characterization. By performing operations of deletion and substitution on expressions of quantity, 1) we succeeded in segmenting binominal phrases into two constituants, 2) we also found that either constituant could act as head of the phrase, 3 ) and we established a scale of definition and determination governing the occurrence of determiners. By comparing English and French definiteness and determination markers, we have established a set of equivalences for each of the two nouns markers (DET).

These findings are restricted to one class of NN phrases, which we have labelled for the sake of convenience, and do not apply to other classes, such as that of phrases which have corresponding single lexical entries in the target language, for instance. They do, however, provide the translator with a set of rules which can not only come the rescue of the translator when his native intuition or «l'usage » fail him, but also account for the latter.

IRÈNE V. SPILKA

APPENDIX

Strict specification in corpus

\begin{tabular}{|c|c|c|}
\hline Exclamation mark & $\rightleftarrows$ & Point d'exclamation \\
\hline Telephone call & & Coup de téléphone \\
\hline$A$ home attitude & & Une atmosphère d'intimité \\
\hline $\begin{array}{c}\text { Person-to-person } \\
\text { transaction }\end{array}$ & & $\begin{array}{l}\text { Échange (amical) de } \\
\text { personne à personne }\end{array}$ \\
\hline Inventory trouble & & Difficultés de recouvrement \\
\hline Business talk & & Questions d'affaires \\
\hline
\end{tabular}

